\title{
The effect of clover-rich diets on cows in mid lactation: production, behaviour and nutrient use
}

\author{
G.P. COSGROVE ${ }^{1}$, J.L. BURKE ${ }^{2}$, A.F. DEATH ${ }^{1}$, G.A. LANE ${ }^{1}$, K. FRASER ${ }^{1}$ and D. PACHECO ${ }^{1}$. \\ ${ }^{1}$ AgResearch Grasslands, $P B$ 11008, Palmerston North \\ ${ }^{2}$ Massey University, PB 11222, Palmerston North \\ gerald.cosgrove@agresearch.co.nz
}

\begin{abstract}
Mixed species pastures typically have insufficient clover to capture its high nutritional value as extra milk production. This paper reports interim results of a study investigating novel methods of presenting white-cloverrich diets to cows. Cows were offered continuous, free access to grass and clover growing separately side-byside in the same paddock $(\mathrm{G} / \mathrm{C})$, or grass-only at night between the afternoon and morning milking and cloveronly during the day between the morning and afternoon milking $(\mathrm{GnCd})$. These treatments were compared against controls of grass-only pasture (Grass) and mixed grassclover pasture (Mix; 92\% grass, $8 \%$ clover). Cows offered $\mathrm{G} / \mathrm{C}$ or $\mathrm{GnCd}$ produced 2.0 and $1.9 \mathrm{~kg} \mathrm{MS} / \mathrm{cow} /$ day, respectively, compared with $1.5 \mathrm{~kg} \mathrm{MS} / \mathrm{cow} /$ day for cows grazing Grass and Mix. The AM and PM milkfat of cows grazing $\mathrm{G} / \mathrm{C}$ contained high levels of skatole, an indicator of protein digestion and metabolism, compared with Grass and Mix. For GnCd, levels were high only in the PM milk and low in the AM milk following the grass-only diet at night. The GnCd cows grazed proportionately more during the 'day' and less at 'night' than the G/C cows. Manipulating the spatial and temporal allocation of grass and white clover to align nutrient allocation with the nutritional and behavioural needs of the cow boosts MS production, but there is scope to improve the efficiency of protein utilisation in the rumen.
\end{abstract}

Keywords: grass, white clover, milk production, grazing behaviour, skatole

\section{Introduction}

The nutritional value of legumes for high milk production is well-established (Rogers et al. 1982; Beever et al. 1986; Harris et al. 1997). Cows produce more milk on legume than on grass diets because the nutritive value of grass is lower (Ulyatt 1981). Use of nitrogen (N) fertiliser on grass only partially remedies this, as even at the same level of nitrogen intake from $\mathrm{N}$-fertilised grass or clover, animal performance is $15 \%$ greater on a clover diet (Ulyatt 1981; Thomson 1984). However, the potential of legumes is seldom realised in practice because grazed dairy pastures in NZ typically contain insufficient legume.

Previous studies indicate gains in production, above that achieved from typical mixed grass-clover pastures, when cows are given continuous free access to ryegrass and white clover growing separately side-by-side in the same paddock (Nuthall et al. 2000; Marotti et al. 2001; Rutter et al. 2003). However, despite the productive benefits, and the opportunities that spatial separation may provide for sustaining a pasture composition that more closely matches preference (Newman et al. 1992; Parsons et al. 1994) and nutrient requirements of lactating cows, growing these species separately within the same paddock may present practical challenges. Rutter et al. (2001) proposed, instead, a temporal separation in the grazing of these two species, meaning they could be grown in separate paddocks. Although over the course of 24 hours animals still get a clover-rich diet, such a method of allocation precludes them from eating both species during each bout of grazing during the day, and this asynchrony may affect production and nutrient utilisation compared with free access to adjacent monocultures.

This paper reports results from a project investigating novel methods of forage presentation to cows, to enhance the proportion of legume in their diet. The hypothesis we tested was that temporal separation in feeding grass (at night) and white clover (during the day) to cows in midlactation would be as good for milk production as giving them continuous free access to both grass and clover. The responses to these contrasting methods of pasture allocation were evaluated in terms of milk production, grazing behaviour and nutrient metabolism.

\section{Materials and Methods}

This study was conducted between November 8 and December 15, 2004, on the Massey University No 1 Dairy Unit, located on Manawatu sandy loam soils adjacent to the Manawatu River.

\section{Treatments and experimental design}

Four treatments were compared. Two treatments consisted of spatial and temporal arrangements of grass and white clover allocated to cows as follows: i) continuous free access to grass and white clover growing separately as side-by-side monocultures (G/C) and ii) clover-only during the 'day' between morning and afternoon milking and grass-only at 'night' between the afternoon and morning milking ( $\mathrm{GnCd}$ ). These were compared against 
controls of iii) a typical mixed grass-white clover pasture (Mix; an industry standard) and iv) a grass-only pasture (Grass; a forage standard). The mixed pasture contained $8 \pm 5 \%$ clover and $92 \pm 5 \%$ grass (proportion of green DM above ground level).

Four groups of spring-calving cows $(n=8)$ in midlactation were allocated to each of four treatments in a balanced, cross-over design with four periods. Cows grazed each treatment for 8 days. They then returned to a single group and grazed a grass paddock for a 2 day wash-out period before moving to the next treatment in the pre-determined sequence. The experimental unit was the group mean.

\section{Animals}

Thirty-two spring-calving Friesian cows $(482 \pm 72 \mathrm{~kg}$; mean $\pm \mathrm{SD}$ ) in their 3rd to 7 th lactation were separated from the main herd and allocated to four groups balanced for age ( $4.9 \pm 1.1$ years), days in milk ( $91 \pm 19$ days as at November 8) and Production Worth index (117/76). Cows were dosed with a Rumensin ${ }^{\circledR}$ antibloat capsule prior to starting the experiment and dosed twice daily at milking with Bloateze $(700 \mathrm{~g} / \mathrm{L}$ alcohol ethoxylate and $70 \mathrm{~g} / \mathrm{L}$ ethylene/propylene co-polymer; FIL, Mount Manganui). Water troughs were treated daily with Bloateze for additional protection.

\section{Pastures}

The trial used nine paddocks of resident mixed-age grassclover pastures. In four recently sown paddocks, ryegrass predominated and five contained a mix of grass species. Four paddocks consisting of adjacent grass and clover monocultures in the area ratio of $0.25: 0.75$ were created by using selective herbicides to remove grass (creating the white clover monoculture) or white clover (creating the grass monoculture). The grass-only treatment used two paddocks of grass monoculture created by selectively removing clover, and the Mix treatment used two paddocks of the resident pasture. Paddocks were blocked according to endophyte strain in the ryegrass, which consisted of wild-type endophyte in older paddocks and AR1 in more recently sown paddocks. Within each 8 day measurement period, cows grazed paddocks containing ryegrass with wild-type endophyte for 4 days and AR1 endophyte for 4 days, to ensure treatment and period were not confounded by endophyte status. Urea was applied to the grass-only and mixed pasture areas at $35 \mathrm{~kg} \mathrm{~N} / \mathrm{ha}, 6$ times annually.

\section{Pasture allocation}

The total daily feed allowance for each group of $54 \mathrm{~kg}$ $\mathrm{DM} /$ cow/day was offered as fresh breaks twice daily in the proportions of $40 \%$ following the morning milking and $60 \%$ following the afternoon milking. Pasture mass was assessed using a rising-plate meter (Farmworks Precision Farming Systems, Feilding), calibrated separately for grass and clover. Allocation protocols included target minimums for pre-grazing and postgrazing mass of 2400 and $1600 \mathrm{~kg} \mathrm{DM} / \mathrm{ha}$, respectively. For $\mathrm{G} / \mathrm{C}$, the total area to be allocated ( 0.75 clover: 0.25 grass) was calculated using the lesser of the mass of grass or clover.

\section{Measurements}

Pasture composition: Samples of grass, clover or mixed pasture were taken by hand plucking to represent the diet being consumed by the cows. These samples were collected on five occasions during the trial at 8:00 AM and 5:00 PM to characterise the diet contributing to the milk harvested at the afternoon and following morning milking, respectively. Samples were stored frozen, and subsequently freeze-dried, ground to pass a $1 \mathrm{~mm}$ sieve and analysed for concentrations of protein, water soluble carbohydrate and fibre, organic matter digestibility and metabolisable energy density by near-infrared reflectance spectroscopy (FeedTech, AgResearch Grasslands, Palmerston North).

Milk production: Milk yield was recorded at each milking using Metatron ${ }^{\mathrm{TM}}$ (Westfalia, Germany) meters and proportional in-line samplers. Milk samples were collected at the PM and following AM milking on days 2, 5 and 8 during each 8-day period, and analysed for fat, protein and lactose content (FT 6000 Fourier Transform infrared analyser, Foss Electric, Hillerød, Denmark). Milk yield data are presented as the treatment mean of the PM plus AM yield for the last 3 days of each measurement period. Milk composition is the treatment mean of samples collected at the final samplings of each period, and, together with yield for that 24 -h period, was used to estimate milksolids production for each treatment.

Grazing behaviour: Cows were observed continuously for two consecutive, 24-h days at the end of each period to determine the time spent grazing during the 'day' and during the 'night'. Each of two observers recorded activity for two groups of eight cows, noting at 1 minute intervals whether or not they were grazing and for $\mathrm{G} / \mathrm{C}$ whether they were grazing grass or clover. Day and night refer to the intervals between successive milkings. Cows were removed from pasture at 6:30 $\mathrm{AM}$ and 3:00 $\mathrm{PM}$ and were off pasture for approximately $2 \mathrm{~h}$ at each milking. The 'night' included approximately 3-4 h of daylight following afternoon milking until dusk (on November 8 sunrise was at 06:00 hours and sunset at 20:10 hours). The total time available for grazing during the 'day' was 450 minutes and during the 'night' 810 minutes.

Milkfat skatole: The concentration of skatole in milkfat was measured as an indicator of protein digestion and metabolism in the contrasting forage treatments. Milk 
samples at the final PM and AM milking of each 8-day period were subsampled and individual cow samples within each treatment group and milking time pooled. Milkfat was extracted from these pooled subsamples, stored at $-20{ }^{\circ} \mathrm{C}$ for subsequent analysis for skatole concentration (ng/g milkfat) by HPLC with fluorescence detection (Lane et al. 2002).

\section{Statistical analysis}

Treatment means and interactions with time ('day' vs. 'night' for grazing behaviour and AM vs. PM for milkfat metabolites) were compared by ANOVA after partitioning group and period effects. In the ANOVA, time was included as a strip-plot factor (sub-plot in strips; Cochran \& Cox 1957). For milk yield and composition, separate analyses were conducted for AM, PM and daily totals.

\section{Results}

\section{Pasture chemical composition}

The chemical composition of pastures offered to cows following milking in the morning (AM sample) and in the afternoon (PM sample) is shown in Table 1. For Grass, Mix and G/C the AM pasture differed from PM pasture mainly in the lower concentration of WSC. For $\mathrm{GnCd}$ the diet was characterised by the diurnal switch from clover (AM) to grass (PM), and this accentuated the diurnal difference in WSC (140 and $214 \mathrm{~g} \mathrm{WSC} / \mathrm{kg}$ DM for AM and PM, respectively), and included a difference in protein concentration (282 and $186 \mathrm{~g}$ protein/ $\mathrm{kg}$ DM for AM and PM, respectively).

\section{Milk yield and composition}

Cows offered G/C or GnCd produced 27.1 and $25.1 \mathrm{~kg}$ milk/cow/day, respectively, compared with 20.6 and 20.5 $\mathrm{kg} / \mathrm{cow} /$ day when offered Grass or Mix, respectively ( $\mathrm{P}<0.01$, SEM 0.3) (Fig. 1). Milksolids yields were 2.0 and $1.9 \mathrm{~kg} \mathrm{MS} / \mathrm{cow} /$ day for $\mathrm{G} / \mathrm{C}$ and $\mathrm{GnCd}$, respectively, and $1.5 \mathrm{~kg} \mathrm{MS} /$ cow/day for Mix and Grass $(\mathrm{P}<0.05$, SEM 0.03).

\section{Grazing behaviour}

The distribution of grazing between day and night differed among treatments (treatment $\mathrm{x}$ time of day interaction $\mathrm{P}<0.001$, SEM 17.5). The $\mathrm{G} / \mathrm{C}$ cows grazed more at night $(261 \mathrm{~min})$ and less during the day (194 min) (Fig. 2) compared with GnCd cows which grazed more during the day than the night ( 249 vs. $214 \mathrm{~min}$ ). $\mathrm{GnCd}$ constrained the cows to spend less time eating clover than those offered G/C (250 vs. 365 min eating clover during $24 \mathrm{~h}$ ) and more time grazing grass (215 vs. $90 \mathrm{~min}$ in $24 \mathrm{~h}$ ).

\section{Milkfat skatole}

The contrasting temporal and spatial allocations of grass and clover had a large effect on skatole concentrations in AM and PM milk (Fig. 3). Concentrations were higher in PM milk than AM milk and were higher for $\mathrm{G} / \mathrm{C}$ than for Grass or Mix. However, there was a pasture treatment $\mathrm{x}$ time of milking interaction ( $\mathrm{P}<0.001$, SEM 177). The $\mathrm{GnCd}$ resulted in the highest concentration of any treatment in the PM milkfat (after an all-day diet of clover), but the concentration in the AM milkfat (following an all-night diet of grass) was as low as Grass and Mix.

\section{Discussion}

Growing grass and clover separately instead of as a mixture, as proposed by Chapman et al. (1996; and see

Table 1 The concentrations (mean \pm SD, $\mathrm{g} / \mathrm{kg} \mathrm{DM}$ ) of protein (PROT), water soluble carbohydrate (WSC), neutral detergent fibre (NDF), organic matter digestibility (OMD) and metabolisable energy (ME, MJ/kg $\mathrm{DM}$ ) of grass ( $\mathrm{gr}$ ) and clover (cl) pastures offered to cows in the morning (AM) and in the afternoon (PM) as four treatments consisting of Grass, mixed grass-white clover (Mix; $8 \pm 5 \%$ clover and $92 \pm 5 \%$ grass), continuous free access to grass and white clover (G/C) and grass at night and clover during the day $(\mathrm{GnCd})$.

\begin{tabular}{lllccccc}
\hline Time & Treatment & Species & PROT & WSC & NDF & OMD & ME \\
\hline AM & Grass & gr & $188 \pm 35$ & $165 \pm 8$ & $537 \pm 27$ & $751 \pm 45$ & $11.6 \pm 0.4$ \\
& Mix & gr+cl & $200 \pm 19$ & $156 \pm 18$ & $508 \pm 35$ & $738 \pm 42$ & $11.4 \pm 0.6$ \\
& G/C & gr & $186 \pm 40$ & $159 \pm 4$ & $534 \pm 43$ & $736 \pm 23$ & $11.4 \pm 0.3$ \\
& & $\mathrm{cl}$ & $270 \pm 12$ & $149 \pm 6$ & $447 \pm 13$ & $838 \pm 12$ & $12.6 \pm 0.2$ \\
& & mean & 253 & 151 & 464 & 817 & 12.4 \\
& GnCd & $\mathrm{cl}$ & $282 \pm 5$ & $140 \pm 13$ & $435 \pm 11$ & $845 \pm 19$ & $12.7 \pm 0.2$ \\
PM & Grass & $\mathrm{gr}$ & $185 \pm 24$ & $201 \pm 5$ & $505 \pm 38$ & $784 \pm 40$ & $12.2 \pm 0.4$ \\
& Mix & $\mathrm{gr}+\mathrm{cl}$ & $191 \pm 29$ & $190 \pm 7$ & $503 \pm 37$ & $775 \pm 43$ & $12.0 \pm 0.5$ \\
& G/C & $\mathrm{gr}$ & $190 \pm 28$ & $197 \pm 6$ & $511 \pm 28$ & $776 \pm 46$ & $12.1 \pm 0.6$ \\
& & $\mathrm{cl}$ & $246 \pm 10$ & $183 \pm 9$ & $463 \pm 22$ & $868 \pm 22$ & $13.2 \pm 0.3$ \\
& & mean & 235 & 186 & 473 & 849 & 13.0 \\
& GnCd & $\mathrm{gr}$ & $186 \pm 29$ & $214 \pm 20$ & $468 \pm 45$ & $808 \pm 35$ & $12.5 \pm 0.3$ \\
\hline
\end{tabular}

${ }^{1}$ Mean of grass and clover in $\mathrm{G} / \mathrm{C}$ weighted according to the proportion of time grazing each component 
Figure 1 The yield of milksolids (kg/cow/d) at the morning (AM) and afternoon (PM) milking of cows offered Grass, mixed grass-white clover (Mix), continuous free access to grass and white clover (G/C) and grass at night and clover during the day $(\mathrm{GnCd})$ (LSD ${ }_{0.05}$ for comparison among treatment means of AM or PM milksolids 0.034).

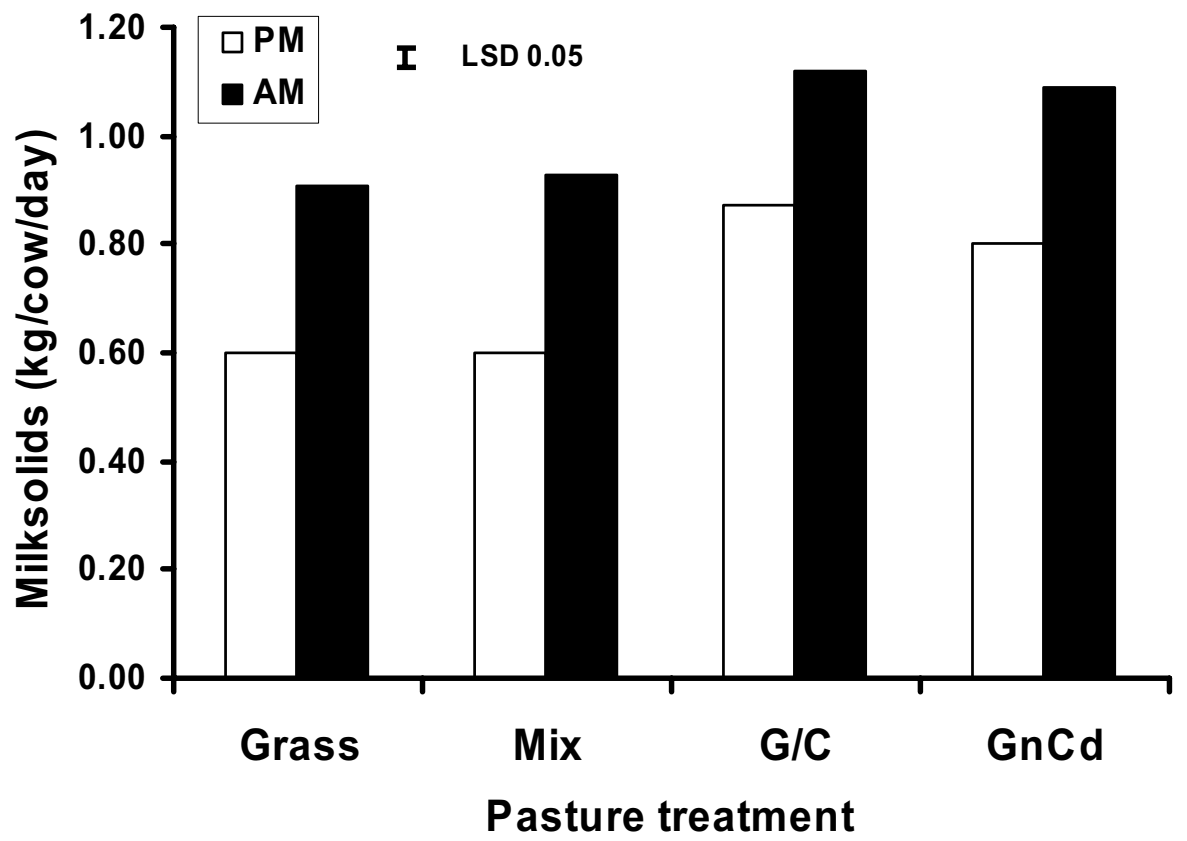

Figure 2 The duration of grazing (min) during the night and during the day by cows offered Grass, mixed grass-white clover (Mix), continuous free access to grass and white clover $(\mathrm{G} / \mathrm{C})$ and grass at night and clover during the day $(\mathrm{GnCd})$ ( $\mathrm{LSD}_{0.05}$ for comparisons among treatment means for different periods of the day 28).

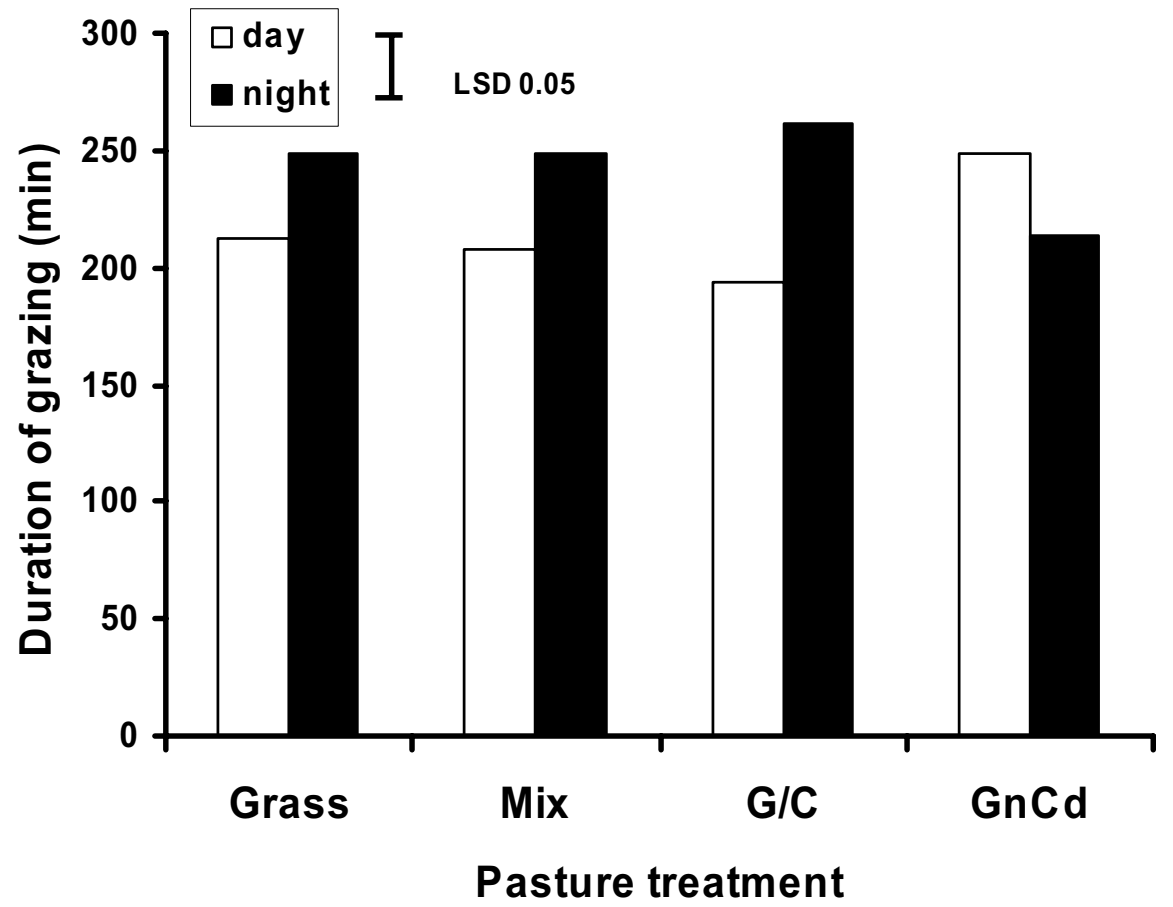


Figure 3 The concentration of skatole in the milkfat ( $\mathrm{ng} / \mathrm{g})$ at the afternoon (PM) and morning (AM) milking of cows offered Grass, mixed grass-white clover (Mix), continuous free access to grass and white clover $(\mathrm{G} / \mathrm{C})$ and grass at night and clover during the day $(\mathrm{GnCd})$ (LSD ${ }_{0.05}$ for comparisons among treatment means for AM or PM skatole 253).

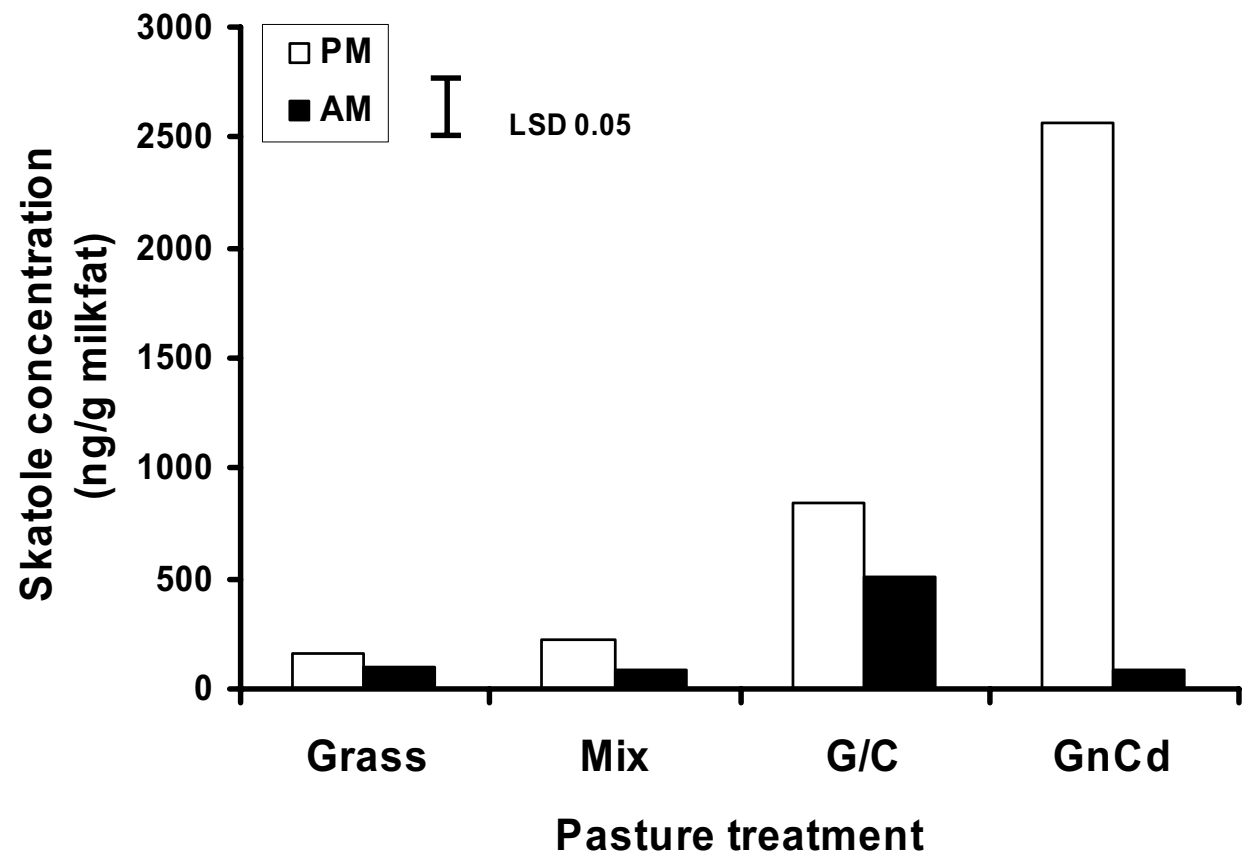

reviews by Chapman et al. 2006; Parsons et al. 2006), allows greater control over the proportions of grass and clover grown and offered to animals. In this study, using novel pasture arrangements, and so sustaining a higher proportion of clover in the diet, MS production per cow increased by $25 \%(\mathrm{GnCd})$ to $30 \%(\mathrm{G} / \mathrm{C})$ compared with Grass or a mixed pasture containing $8 \%$ clover (Mix). The increase for $\mathrm{G} / \mathrm{C}$ compared with Grass is consistent with results reported by Nuthall et al. (2000) and Marotti et al. (2001), but greater than that recorded for cows in late lactation (Cosgrove et al. 2006). It is not clear if this difference between trials relates to stage of lactation per $s e$, or seasonal differences in the chemical composition of the grass and/or clover. There were only minor differences between November/December and April in the concentrations of protein and carbohydrate of the grass and clover, although NDF in grass (grass comprised approximately $20 \%$ of the $\mathrm{G} / \mathrm{C}$ diet and $50 \%$ of the $\mathrm{GnCd}$ diet) tended to be lower in this study than it was in autumn.

The greater MS production from $\mathrm{G} / \mathrm{C}$ and $\mathrm{GnCd}$ appears to result from the greater opportunity to eat clover, as there was no increase in the total time spent grazing on these treatments compared with Grass or Mix, in contrast to results reported by Rutter et al. (2003). One of the benefits of offering animals continuous free access to grass and clover growing separately (G/C), demonstrated by Champion et al. (2004), was that it offered opportunity for a substantial increase in intake (often seen as extended grazing time) compared with Grass or a Mix. The opportunity to eat both grass and clover in close temporal synchrony in G/C may be a significant element of that 'boost'. However, in previous comparable studies (Marotti et al. 2002), there was no 'boost' in the total time spent grazing. This suggests that temporal separation in allocating grass and clover (i.e. $\mathrm{GnCd}$ ) may be a feasible alternative, and it would be simpler to implement than G/C. In GnCd, although the proportion of total grazing time spent eating clover over the course of $24 \mathrm{~h}$ was $50 \%$ compared with $80 \%$ in $\mathrm{G} / \mathrm{C}$, there was no significant reduction in milk production.

The novel spatial and temporal arrangements of grass and clover may affect nutrient digestion and metabolism. Skatole arises in the rumen from the microbial breakdown of tryptophan from dietary proteins (Deslandes et al. 2001) and is influenced by the concentration and intake of dietary proteins (Kebreab et al. 2003). The concentrations of skatole in milkfat for the cows on Grass and Mix were comparable with the levels reported for cows grazing mixed ryegrass-white clover pasture in spring (Lane et al. 2002). However, the much higher concentrations of skatole for $\mathrm{G} / \mathrm{C}$ cows in the morning and afternoon and in the afternoon milkfat for $\mathrm{GnCd}$, appears to be related to the high clover content of these 
diets. Recent studies showed higher concentrations of skatole in the rumen, relative to protein intake, for sheep fed white clover compared with those fed ryegrass (Schreurs et al. 2003).

The diurnal difference in skatole concentration for the Grass, Mix and G/C treatments, was accentuated in $\mathrm{GnCd}$ by eating clover-only during the day. The very high concentration in the PM milk, but the low concentration in the AM milk following overnight feeding on grass, indicates no carry-over from one milking to the next. The higher concentration of skatole in PM compared with AM milk has previously been attributed primarily to the different intervals between successive milkings and the resulting difference in the time for indolic compounds to clear from the cow (Tavendale et al. 2005), although the diurnal difference in WSC concentration of the forage may also be a factor. The high concentration of skatole in the PM milk from $\mathrm{GnCd}$ may also reflect a behavioural response by the cows grazing this treatment. Of all the treatments, $\mathrm{G} / \mathrm{C}$ provided the greatest freedom for cows to eat their preferred diet and distribute their grazing as they wished, whereas the $\mathrm{GnCd}$ cows were constrained temporally. On the basis of time spent grazing, the intake of clover during the day was estimated to be approximately $60 \%$ higher for the $\mathrm{GnCd}$ cows compared with the G/C cows. This high intake of clover in the short interval between $\mathrm{AM}$ and PM milking (approximately $8 \mathrm{~h}$ ), and the rapid degradation of this large quantity of protein in the rumen may have contributed to the high concentration of skatole in PM milkfat.

Novel approaches to growing and allocating forages, such as tested here, can align the species composition of pasture with the animals' own goals in nutrient intake, sustain the provision of high legume diets, and better capture the high nutritive value of legumes as increased milksolids. The high levels of indolic compounds in the milkfat of the cows on $\mathrm{G} / \mathrm{C}$ and $\mathrm{GnCd}$ suggest there is scope to improve the efficiency of protein utilisation in the rumen and further enhance the precision of nutrient allocation to grazing animals and their production from clover-rich diets. Greater precision in nutrient allocation may in future contribute to meeting more demanding targets in product composition (e.g. flavour, fatty acid profiles) and in environmental standards (e.g. nitrates, methane). These are influenced by diet composition, and successful delivery to these goals by modification of plant traits will depend critically on precise, targeted allocation of pastures.

\section{ACKNOWLEDGEMENTS}

This project was conducted with funding from Dairy InSight, The Foundation for Research, Science and Technology and the C Alma Baker Trust.
The assistance from Rochelle Lamb with trial management, Fred Potter for statistical design and analyses, Lex Foote for establishment and maintenance of experimental pastures, Mike Hickey for preparation of pasture samples, Bruce Sinclair for sample handling protocols, and Carlos Ramirez-Restrepo for determining botanical composition is gratefully acknowledged. Thanks to staff of Agricultural Services and of the No 1 Dairy Unit of Massey University for access to facilities and assistance with the conduct of the trial. Numerous students of Massey University assisted with observation of cows.

\section{REFERENCES}

Beever, D.E.; Losada, H.R.; Cammell, S.B.; Evans, R.T.; Haines, M.J. 1986. Effect of forage species and season on nutrient digestion and supply in grazing cattle. British Journal of Nutrition 56: 209-225.

Champion, R.A.; Orr, R.J.; Penning, P.D.; Rutter, S.M. 2004. The effect of spatial scale of heterogeneity of two herbage species on the grazing behaviour of lactating sheep. Applied Animal Behaviour Science 88: 61-76.

Chapman, D.F.; Parsons, A.J.; Schwinning, S. 1996. Management of clover in grazed pasture: expectations, limitations and opportunities. White Clover: New Zealand's Competitive Edge. Agronomy Society of New Zealand Special Publication 11/Grasslands Research and Practice Series 6: 55-64.

Chapman, D.F.; Parsons, A.J.; Cosgrove, G.P.; Barker, D.J.; Marotti, D.M.; Venning, K.; Rutter, S.M.; Thompson, A.N. 2006. Impacts of spatial patterns in pasture on animal grazing behaviour, intake and performance. Crop Science: in press.

Cochran, W.G.; Cox, G.M. 1957. Experimental designs. 2nd edition, Wiley, New York.

Cosgrove, G.P.; Burke, J.L.; Death, A.F.; Lane, G.A.; Fraser, K.; Pacheco, D.; Parsons, A.J. 2006. Cloverrich diets and production, behaviour and nutrient use by cows in late lactation. Proceedings of the New Zealand Society of Animal Production 66: 42-49.

Deslandes, B., Gariépy, C; Houde, A. 2001. Review of microbiological and biochemical effects of skatole on animal production. Livestock Production Science 71: 193-200.

Harris, S.L.; Clark, D.A.; Jansen, E.B.L. 1997. Optimum white clover content for milk production. Proceedings of the New Zealand Society of Animal Production 57: 169-171.

Kebreab, E.; France, J.; Mills, J.A.; Allison, R.; Dijkstra, J. 2002. A dynamic model of $\mathrm{N}$ metabolism in the lactating dairy cow and an assessment of impact of $\mathrm{N}$ excretion on the environment. Journal of Animal Science 80: 248-259. 
Lane, G.A.; Fraser, K.; Kolver, E.S.; Rowan, D.D.; Allen, J.M.; Mills, O.E.; Abraham, A.S.; Olney, S.D. 2002. Effect of a total mixed ration diet on the concentration of amino acid-derived volatiles in milk. Proceedings of the New Zealand Society of Animal Production 62: 242-245.

Marotti, D.M.; Cosgrove, G.P.; Chapman, D.F.; Parsons, A.J.; Egan, A.R.; Anderson, C.B. 2001. Novel methods of forage presentation to boost nutrition and performance of grazing dairy cows. Australian Journal of Dairy Technology 56: 159.

Marotti, D.M.; Cosgrove, G.P.; Chapman, D.F.; Parsons, A.J.; Egan, A.R.; Anderson, C.B. 2002. Growing grass and clover separately allows animals to sustain a high nutrient intake. Proceedings of the New Zealand Society of Animal Production 62: 163-166.

Newman, J.A.; Parsons, A.J.; Harvey, A. 1992. Not all sheep prefer clover: diet selection revisited. Journal of Agricultural Science 119: 275-283.

Nuthall, R.; Rutter, S.M.; Rook, A.J. 2000. Milk production by dairy cows grazing mixed swards of adjacent monocultures of grass and white clover. pp. 37-38. In: 6th BGS Research Conference. British Grasslands Society.

Parsons, A.J., Newman, J.A., Penning, P.D., Harvey, A., Orr, R.J. 1994. Diet preference of sheep: effects of recent diet, physiological state, and species abundance. Journal of Animal Ecology 63: 465-478.

Parsons, A.J.; Edwards, G.R.; Chapman, D.F.; Carran, R.A. 2006. How far have we come: 75 years in 'clover'? Proceedings of the New Zealand Grassland Association 68: XXX-XXX.

Rogers, G.L.; Porter, R.H.D.; Robinson, I. 1982.
Comparison of perennial ryegrass and white clover for milk production. pp. 213-214. In: Dairy production from pasture. Proceedings of the New Zealand and Australian Society of Animal Production.

Rutter, S.M.; Nuthall, R.A.; Champion, R.A.; Orr, R.J.; Rook, A.J. 2001. Preference for grass and clover by dairy cattle: is free choice important? pp. 148 In: Proceedings of the 35th International Congress of the International Society of Applied Ethology, Davis, California.

Rutter, S.M.; Young, K.L.; Cook, J.E.; Champion, R.A. 2003. Strip-grazing separate white clover and ryegrass monocultures increases daily intake and milk yield in dairy cows. Tropical and Subtropical Agroecosystems 3: 461-465.

Schreurs, N.M.; Tavendale, M.H.; Lane, G.A., Barry, T.N.; Marotti, D.M.; McNabb, W.M. 2003. Postprandial indole and skatole formation in the rumen when feeding white clover, perennial ryegrass and Lotus corniculatus. Proceedings of the New Zealand Society of Animal Production 63: 14-17.

Tavendale, M.H.; Lane, G.A.; Fraser, K.; Yeoman, J.; Burke, J.L.; Cosgrove, G.P.; Pacheco, D. 2005. Diurnal variations in flavour chemistry in the rumen and milk of dairy cows grazing pasture. pp. 77. In: Proceedings of the 3rd Dairy3 conference. Ed. I.M. Brookes.

Thomson, D.J. 1984. The nutritive value of white clover. pp. 78-92. In: Forage legumes. D.J. Thomson Ed. Occassional Symposium No 16. British Grassland Society

Ulyatt, M.J. 1981. The feeding value of herbage: Can it be improved? New Zealand Agricultural Science 15(4): 200-205. 